\title{
Penerapan Metode Naive Bayes Dalam Pemilihan Kualitas Jenis Rumput Taman CV. Rumput Kita Landscape
}

\author{
Sri Rahayu ${ }^{1}$, Anita Sindar RM Sinaga ${ }^{2}$ \\ ${ }^{1,2}$ STMIK Pelita Nusantara \\ 1,2Program Studi Teknik Informatika STMIK Pelita Nusantara \\ Jl. Iskandar Muda No. 1 Medan Indonesia Telp. 06188813414 \\ e-mail: ${ }^{1}$ rahayusri710@gmail.com, ${ }^{2}$ haito_ita@yahoo.com
}

\begin{abstract}
Abstrak
Penataan taman yang menarik, sejuk dan indah memerlukan budget yang tinggi. Dari beragam jenis rumput, umumnya Rumput Mini ditanam untuk mempercantik rumah atau bangunan. Para pengelola jasa taman menentukan kualitas rumput dari pengalaman seharihari. Ini menunjukkan belum adanya pemanfaatan sistem komputer dalam pemilihan jenis rumput taman yang berkualitas, menyebabkan terjadi kesalahan dalam menentukan kualitas rumput terbaik. Dalam permasalahan ini metode Nä̈ve Bayes digunakan sebagai Sistem Pengambil Keputusan (SPK). Nä̈ve bayes merupakan metode pengklasifikasian ada tidaknya ciri tertentu dari sebuah kelas. Empat kriteria pemilihan kualitas jenis rumput taman yaitu suhu udara, curah hujan, kelembapan udara dan harga pasar. Hasil perangkingan dari R1, R2, R3, R4, R5, R6, R7 menunjukkan R6: Rumput Golf= 0.4705882353; R7: Rumput Swiss= 0.4705882353 merupakan rumput yang memiliki Kualitas Baik.
\end{abstract}

Kata Kunci: Pemilihan Rumput, Kualitas, Ranking, Nä̈ve Bayes

Abstract
An attractive, cool and beautiful garden arrangement requires a high budget. Of the various types of grass, generally Mini Grass is planted to beautify your home or building. The managers of garden services determine the quality of grass from everyday experience. This shows that there is no use of computer systems in the selection of quality garden grass types, causing errors in determining the best quality of grass. In this problem the Näive Bayes method is used as a Decision Making System (SPK). Nä̈ve Bayes is a method of classifying the presence or absence of certain characteristics of a class. Four criteria for selecting the quality of garden grass types are air temperature, rainfall, air humidity and market prices. The ranking results of R1, R2, R3, R4, R5, R6, R7 indicate R6: Golf Grass = 0.4705882353; R7: Swiss grass = 0.4705882353 is a grass that has good quality.

Keywords: Selection Of Grass, Quality, Ranking, Nä̈ve Bayes

\section{Pendahuluan}

Bagi sebagian masyarakat, rumput menjadi tanaman pengganggu namun beberapa orang mengembangbiakkan dengan cara menanam langsung pada tanah. Penyedia jasa taman menawarkan jenis rumput tentu harus disesuaikan dengan kondisi tanah dan tingkat pemeliharaannya. Setiap rumput memiliki kualitas yang berbeda-beda, semakin baik kualitas rumput yang dipilih akan lebih mudah menanam dan memelihara misalnya tampilan taman akan semakin indah dan memiliki nilai seni yang tinggi maupun memiliki harga jual. Apabila masyarakat salah dalam memilih jenis rumput yang berkualitas maka yang akan terjadi adalah akan mengurangi nilai seni yang terkandung didalamnya bahkan akan mengurangi harga jual rumput [1]. 
Ruang lingkup permasalahan dalam proses pembudidayaan jenis rumput taman dengan metode Naive Bayes yaitu pemilihan kualitas jenis rumput taman dalam pembudidayaan ini menggunakan 7 jenis rumput yaitu : Gajah Mini, Gajah Mini Variegata, Rumput Paeking, Rumput Paitan, Rumput Jepang, Rumput Swiss, dan Rumput Golf. Dalam menentukan pemilihan kualitas jenis rumput taman berdasarkan dari 4 kriteria yaitu : suhu udara, curah hujan, kelembapan udara, harga pasar. Beberapa teknik yang dapat digunakan untuk membantu dalam pemilihan jenis rumput salah satunya adalah dengan menggunakan sistem pendukung keputusan. Dalam menentukan keputusan yang terbaik diperlukan Sistem Pengambil Keputusan (SPK) dengan prosedur-prosedur berdasarkan sistem informasi berbasis komputer dan pengetahuan [2]. Pada metode Naive Bayes proses klasifikasi memerlukan sejumlah petunjuk untuk menentukan kelas yang cocok bagi permasalahan [3]. Teorema Bayes mengasumsikan semua atribut independen atau tidak saling ketergantungan yang diberikan oleh nilai pada variabel kelas. Naive Bayes juga didefenisikan sebagai pengklasifikasian dengan metode probabilitas dan statistik yang dikemukakan oleh ilmuan Inggris Thomas Bayes, yaitu memprediksi peluang dimasa depan berdasarkan pengalaman dimasa sebelumnya [4], [5].

\section{Metode Penelitian}

\subsection{Analisis sistem}

Analisa sistem dilakukan sebelum implementasi perancangan, bertujuan untuk menganalisa sumber data, pokok permasalahan dan hambatan-hambatan yang mengganggu proses berjalan. Kriteria pemilihan rumput untuk landscape didasarkan pada pertimbangan keunikan, kondisi lahan, kadar menyerap air dan ketahanan pada sinar matahari [6]. Nama-nama rumput taman seperti Rumput Gajah Variegata, Rumput Gajah Mini, Rumput Gajah Biasa, Rumput Jepang/Peking dan Rumput Swiss.

\subsection{Naive Bayes}

Naive Bayes didasarkan pada asumsi penyederhanaan bahwa nilai atribut secara kondisionalsaling bebas jika diberikan nilai output. Dengan kata lain, diberikan nilai output, probabilitas mengamati secara bersama adalah produk dari probabilitas individu

Dalam Bayes (terutama Naive Bayes), maksud independensi yang kuat pada fitur adalah bahwa sebuah fitur data tidak berkaitan dengan ada atau tidaknya fitur lain dalam data yang sama. Naive Bayes classifier (NBC) merupakan salah satu metoda pemelajaran mesin yang memanfaatkan perhitungan probabilitas dan statistik yang dikemukakan oleh ilmuwan Inggris Thomas Bayes, yaitu memprediksi probabilitas di masa depan berdasarkan pengalaman di masa sebelumnya.Ide dasar dari aturan Bayes adalah bahwa hasil dari hipotesa atau peristiwa dapat diperkirakan berdasarkan pada beberapa bukti (E) yang diamati [7], [8].

Tahapan proses Naive Bayes [9] :

1. Menghitung jumlah kelas / label

2. Menghitung Jumlah Kasus Per Kelas

3. Kalikan Semua Variable Kelas

4. Bandingkan Hasil Per Kelas

Prediksi Bayes [10]:

$\mathrm{P}(\mathrm{A} \mid \mathrm{B})=\frac{\mathrm{P}(\mathrm{B} \mid \mathrm{A}) * \mathrm{P}(\mathrm{A})}{\mathrm{P}(\mathrm{B})}$

$\mathrm{P}(\mathrm{A} \mid \mathrm{B})$ : probabilitas A dan B terjadi bersama-sama

$\mathrm{P}(\mathrm{B} \mid \mathrm{A})$ : probabilitas $\mathrm{B}$ dan A terjadi bersama-sama

$\mathrm{P}(\mathrm{A}) \quad$ : probabilitas kejadian $\mathrm{A}$

$\mathrm{P}(\mathrm{B})$ : probabilitas kejadian B 
Tabel 1. Keterangan Prediksi Bayes

\begin{tabular}{|l|l|}
\hline \multicolumn{1}{|c|}{ Parameter } & \multicolumn{1}{|c|}{ Keterangan } \\
\hline P $(\mathrm{A} \mid \mathrm{B})$ & Probabilitas A dan B terjadi bersama-sama \\
$\mathrm{P}(\mathrm{B} \mid \mathrm{A})$ & Probabilitas B dan A terjadi bersama-sama. \\
$\mathrm{P}(\mathrm{A})$ & Probabilitas kejadian A \\
$\mathrm{P}(\mathrm{B})$ & Probabilitas kejadian B \\
\hline
\end{tabular}

Proses data klasifikasi memiliki dua tahap, yang pertama adalah learning: training data dianalisa dengan menggunakan sebuah algoritma klasifikasi [7]. Dan yang kedua adalah Classification: pada tahap ini test data digunakan untuk mengestimasi ketepatan dari classification rules. Jika keakuratan yang dikondisikan dan yang diperkirakan dapat diterima, rule dapat diaplikasikan pada klasifikasi lainnya dari tuple data yang baru. Classification hanya bisa diterapkan pada data training yang sangat kuat dimana diasumsikan bahwa kelas "positif" sudah mewakili minoritas tanpa kehilangan atribut umum [8]. Data yang digunakan sebagai data training biasa bersifat konsisten, tidak konsisten atau biasa.

\subsection{Analisis Sistem yang Dibangun}

Pada Naive Bayes, proses klasifikasi memerlukan sejumlah petunjuk untuk menentukan kelas apa yang cocok bagi sampel yang dianalisis tersebut. Untuk menyelesaikan metode Naive Bayes dibutuhkan algoritma, penerapan algoritma dalam flowchart.

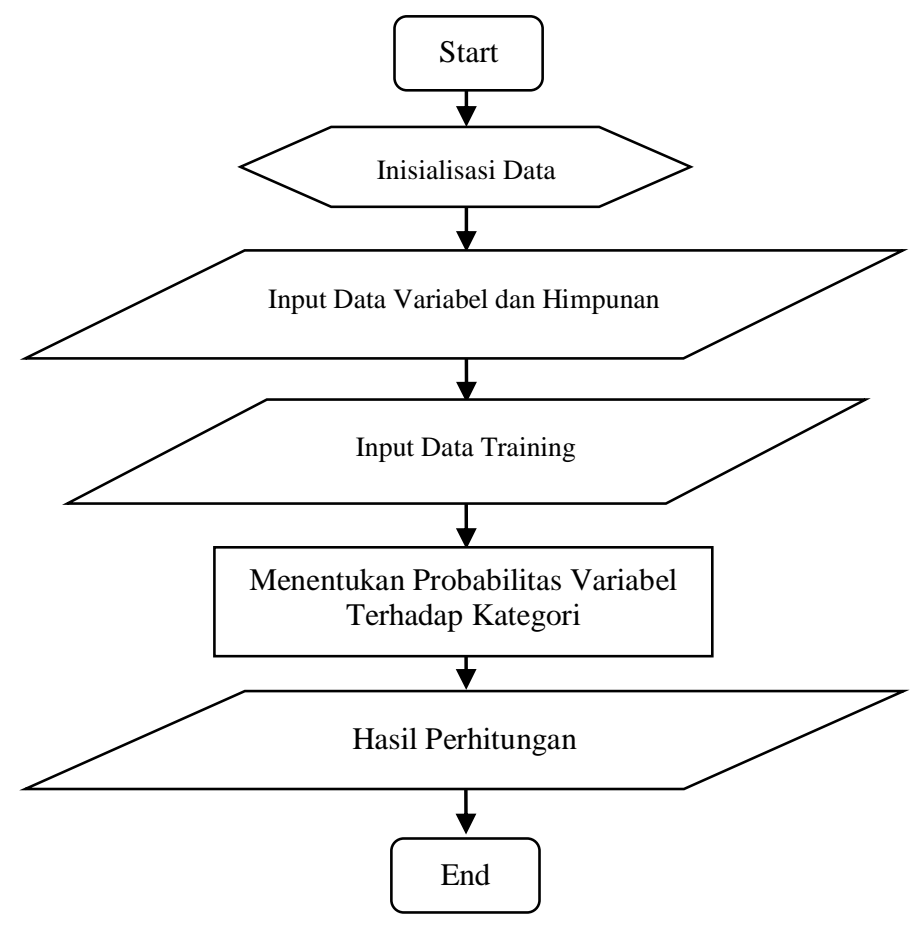

Gambar 1. Flowchart Algoritma Metode Naïve Bayes

\section{Hasil dan Pembahasan}

Langkah-Langkah Metode Naive Bayes

1. Variabel dan Himpunan

Data variabel dan himpunan, pemilihan jenis rumput yang ingin dibudidayakan. 
Tabel 2. Variabel dan Himpunan

\begin{tabular}{|c|l|c|}
\hline Kode & \multicolumn{1}{|c|}{ Nama Kriteria } & Himpunan \\
\hline \multirow{2}{*}{ C1 } & \multirow{2}{*}{ Suhu Udara } & Panas \\
\cline { 3 - 3 } & & Dingin \\
\cline { 3 - 3 } C2 & \multirow{2}{*}{ Curah Hujan } & Tinggi \\
\hline \multirow{2}{*}{ C3 } & \multirow{2}{*}{ Kelembapan Udara } & Rendah \\
\cline { 3 - 3 } & & Tinggi \\
\hline \multirow{2}{*}{ C4 } & \multirow{2}{*}{ Harga Pasaran } & Tinggi \\
\cline { 3 - 3 } & & Rendah \\
\hline
\end{tabular}

Tabel 3. Variabel Dan Himpunan

\begin{tabular}{|c|l|}
\hline Kode & \multicolumn{1}{|c|}{ Nama Rumput } \\
\hline R1 & Gajah Mini \\
\hline R2 & Gajah Mini Variegata \\
\hline R3 & Rumput Paeking \\
\hline R4 & Rumput Paitan \\
\hline R5 & Rumput Jepang \\
\hline R6 & Rumput Swiss \\
\hline R7 & Rumput Golf \\
\hline
\end{tabular}

2. Data Training

Data training merupakan data klasifikasi pemilihan jenis rumput yang ingin dibudidayakan berdasarkan kriteria-kriteria yang ada, Tabel 4. Data testing dalam penelitian ini meliputi Rumput Gajah Mini, Rumput Gajah Mini Variegata, Rumput Paeking, Rumput Paitan, Rumput Jepang, Rumput Swiss dan Rumput Golf.

Tabel 4. Data Training

\begin{tabular}{|c|l|l|l|l|l|}
\hline No & $\begin{array}{c}\text { Suhu } \\
\text { Udara }\end{array}$ & $\begin{array}{c}\text { Curah } \\
\text { Hujan }\end{array}$ & $\begin{array}{c}\text { Kelembapan } \\
\text { Udara }\end{array}$ & $\begin{array}{c}\text { Harga } \\
\text { Pasaran }\end{array}$ & \multicolumn{1}{|c|}{ Jenis Rumput } \\
\hline 1 & Panas & Rendah & Rendah & Rendah & Gajah Mini \\
\hline 2 & Panas & Rendah & Rendah & Tinggi & Gajah Mini Variegata \\
\hline 3 & Panas & Rendah & Rendah & Tinggi & Rumput Paeking \\
\hline 4 & Dingin & Tinggi & Tinggi & Rendah & Rumput Paitan \\
\hline 5 & Dingin & Tinggi & Tinggi & Tinggi & Rumput Jepang \\
\hline 6 & Dingin & Tinggi & Rendah & Tinggi & Rumput Swiss \\
\hline 7 & Dingin & Tinggi & Rendah & Tinggi & Rumput Golf \\
\hline 8 & Panas & Tinggi & Tinggi & Rendah & Gajah Mini \\
\hline 9 & Panas & Tinggi & Rendah & Tinggi & Gajah Mini Variegata \\
\hline 10 & Panas & Tinggi & Rendah & Tinggi & Rumput Paeking \\
\hline 11 & Dingin & Rendah & Tinggi & Tinggi & Rumput Paitan \\
\hline 12 & Dingin & Rendah & Tinggi & Tinggi & Rumput Jepang \\
\hline 13 & Dingin & Rendah & Rendah & Tinggi & Rumput Swiss \\
\hline 14 & Dingin & Rendah & Rendah & Tinggi & Rumput Golf \\
\hline 15 & Dingin & Rendah & Tinggi & Tinggi & Gajah Mini \\
\hline 16 & Dingin & Rendah & Tinggi & Rendah & Gajah Mini Variegata \\
\hline
\end{tabular}




\begin{tabular}{|l|l|l|l|l|l|}
\hline 17 & Dingin & Rendah & Tinggi & Rendah & Rumput Paeking \\
\hline 18 & Panas & Tinggi & Rendah & Tinggi & Rumput Paitan \\
\hline 19 & Panas & Rendah & Rendah & Rendah & Rumput Jepang \\
\hline 20 & Panas & Tinggi & Tinggi & Rendah & Rumput Swiss \\
\hline 21 & Panas & Tinggi & Tinggi & Rendah & Rumput Golf \\
\hline 22 & Panas & Tinggi & Tinggi & Rendah & Gajah Mini \\
\hline
\end{tabular}

3. Menentukan probabilitas variabel terhadap kategori.

Dari data training pada Tabel 3, ditentukan nilai probabilitas dari tiap-tiap variabel kedalam kategori, yaitu :

a) Probabilitas suhu udara pada setiap kategori jenis rumput.

Tabel 5. Probabilitas Suhu Udara

\begin{tabular}{|l|c|c|c|c|c|c|c|c|c|c|c|c|c|c|}
\hline \multirow{3}{*}{ Himpunan } & \multicolumn{4}{|c|}{ Jumlah Kategori Suhu Udara } & \multicolumn{5}{c|}{ Probabilitas Kategori Suhu Udara } \\
\cline { 2 - 17 } & $\mathbf{R 1}$ & $\mathbf{R 2}$ & $\mathbf{R 3}$ & $\mathbf{R}$ & $\mathbf{R 5}$ & $\mathbf{R 6}$ & $\mathbf{R 7}$ & $\mathbf{R 1}$ & $\mathbf{R 2}$ & $\mathbf{R 3}$ & $\mathbf{R 4}$ & $\mathbf{R 5}$ & $\mathbf{R 6}$ & $\mathbf{R}$ \\
\hline Panas & 3 & 2 & 2 & 1 & 1 & 1 & 1 & 0.27 & 0.18 & 0.18 & 0.09 & 0.09 & 0.09 & 0.09 \\
\hline Dingin & 1 & 1 & 1 & 2 & 2 & 2 & 2 & 0.09 & 0.09 & 0.09 & 0.18 & 0.18 & 0.18 & 0.18 \\
\hline
\end{tabular}

Penjelasan :

R1 = Jumlah suhu udara panas Jumlah semua suhu udara panas

$=3 / 11=0.27$

$=\underline{\text { Jumlah suhu udara dingin }}$ Jumlah semua suhu udara dingin

$=1 / 11=0.09$

R2 = Jumlah suhu udara panas Jumlah semua suhu udara

panas

$=2 / 11=0.18$

$=$ Jumlah suhu udara dingin Jumlah semua suhu udara

dngin

$=1 / 11=0.09$

R3 = Jumlah suhu udara panas Jumlah semua suhu udara panas

$$
=2 / 11=0.18
$$

$=$ Jumlah suhu udara dingin Jumlah semua suhu udara

dingin

$=1 / 11=0.09$

R7 = Jumlah suhu udara panas Jumlah semua suhu udara

panas

$$
=1 / 11=0.09
$$

R4 = Jumlah suhu udara panas Jumlah semua suhu udara

panas

$=1 / 11=0.09$

$=\underline{\text { Jumlah suhu udara dingin }}$ Jumlah semua suhu udara

dingin

$$
\begin{aligned}
& =2 / 11=0.18 \\
\text { R5 } & =\frac{\text { Jumlah suhu udara panas }}{\text { Jumlah semua suhu udara }}
\end{aligned}
$$

panas

$$
=1 / 11=0.09
$$

$=\underline{\text { Jumlah suhu udara dingin }}$ Jumlah semua suhu udara

dingin

$$
\begin{aligned}
& =2 / 11=0.18 \\
\text { R6 } & =\frac{\text { Jumlah suhu udara panas }}{\text { Jumlah semua suhu udara }}
\end{aligned}
$$

panas

$=1 / 11=0.09$

$=$ Jumlah suhu udara dingin Jumlah semua suhu udara dingin

$$
=2 / 11=0.18
$$




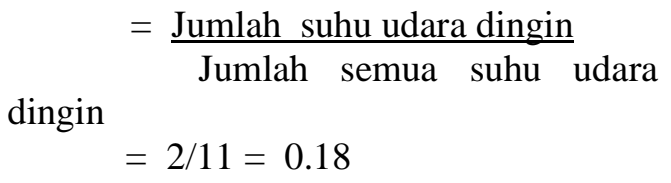

b) Probabilitas curah hujan pada setiap kategori jenis rumput.

Tabel 6. Probabilitas Curah Hujan

\begin{tabular}{|l|c|c|c|c|c|c|c|c|c|c|c|c|c|c|}
\hline \multirow{3}{*}{ Himpunan } & \multicolumn{4}{|c|}{ Jumlah Kategori Curah Hujan } & \multicolumn{5}{|c|}{ Probabilitas Kategori Curah Hujan } \\
\cline { 2 - 26 } & R1 & R2 & R3 & R4 & R5 & R6 & R7 & R1 & R2 & R3 & R4 & R5 & R6 & R7 \\
\hline Rendah & 2 & 2 & 2 & 1 & 2 & 1 & 1 & 0.18 & 0.18 & 0.18 & 0.09 & 0.18 & 0.09 & 0.09 \\
\hline Tinggi & 2 & 1 & 1 & 2 & 1 & 2 & 2 & 0.18 & 0.09 & 0.09 & 0.18 & 0.09 & 0.18 & 0.18 \\
\hline
\end{tabular}

Penjelasan :

R1 = $\underline{\text { Jumlah Curah hujan Rendah }}$ Jumlah keseluruhan curah hujan rendah

$=2 / 11=0.182$

$=$ Jumlah Curah hujan Tinggi Jumlah keseluruhan curah hujan tinggi

$=2 / 11=0.018$

R3 = Jumlah Curah hujan Rendah

rendah Jumlah keseluruhan curah hujan

$=2 / 11=0.18$

$=\underline{\text { Jumlah Curah hujan Tinggi }}$ Jumlah keseluruhan curah hujan tinggi

$=1 / 11=0.09$

R5 = Jumlah Curah hujan Rendah Jumlah keseluruhan curah hujan rendah

$=2 / 11=0.18$

$=$ Jumlah Curah hujan Tinggi

tinggi Jumlah keseluruhan curah hujan

$=1 / 11=0.09$

R7 = Jumlah Curah hujan Rendah Jumlah keseluruhan curah hujan

rendah

$$
=1 / 11=0.09
$$

$=\underline{\text { Jumlah Curah hujan Tinggi }}$

tinggi
R2 = $\underline{\text { Jumlah Curah hujan Rendah }}$ Jumlah keseluruhan curah hujan rendah

$$
=2 / 11=0.18
$$

$=$ Jumlah Curah hujan Tinggi Jumlah keseluruhan curah

hujan tinggi

$$
\begin{aligned}
& =1 / 11=0.09 \\
\text { R4 } & =\frac{\text { Jumlah Curah hujan Rendah }}{\text { Jumlah keseluruhan curah }}
\end{aligned}
$$$$
\text { hujan rendah }
$$

$=1 / 11=0.09$

$=\underline{\text { Jumlah Curah hujan Tinggi }}$ Jumlah keseluruhan curah hujan tinggi

$$
\begin{aligned}
& =2 / 11=0.18 \\
\text { R6 } & =\frac{\text { Jumlah Curah hujan Rendah }}{\text { Jumlah keseluruhan curah }}
\end{aligned}
$$

hujan rendah

$$
=1 / 11=0.09
$$

$=\underline{\text { Jumlah Curah hujan Tinggi }}$

hujan tinggi Jumlah keseluruhan curah

$$
=2 / 11=0.18
$$


c) Probabilitas kelembapan udara pada setiap kategori jenis rumput

Tabel 7. Probabilitas Kelembapan Udara

\begin{tabular}{|c|c|c|c|c|c|c|c|c|c|c|c|c|c|c|}
\hline \multirow{2}{*}{ Himpunan } & \multicolumn{7}{|c|}{ Jumlah Kategori Kelembapan Udara } & \multicolumn{7}{|c|}{ Probabilitas Kategori Kelembapan Udara } \\
\hline & $\mathbf{R 1}$ & $\mathbf{R 2}$ & R3 & R4 & R5 & R6 & R7 & R1 & $\mathbf{R 2}$ & $\mathbf{R 3}$ & $\mathbf{R 4}$ & R5 & R6 & R7 \\
\hline Rendah & 1 & 2 & 2 & 1 & 1 & 2 & 2 & 0.09 & 0.18 & 0.18 & 0.09 & 0.09 & 0.18 & 0.18 \\
\hline Tinggi & 3 & 1 & 1 & 2 & 2 & 1 & 1 & 0.27 & 0.09 & 0.09 & 0.18 & 0.18 & 0.09 & 0.09 \\
\hline
\end{tabular}

Penjelasan :

$\mathrm{R} 1=\underline{\text { Jumlah Kelembapan Udara }}$

$\underline{\text { Rendah }}$

Jumlah keseluruhan Kelembapan

Udara rendah

$=1 / 11=0.09$

$=$ Jumlah Kelembapan Udara Tinggi

Jumlah keseluruhan Kelembapan

Udara tinggi

$=3 / 11=0.27$

$\mathrm{R} 2=\underline{\text { Jumlah Kelembapan Udara }}$

$\underline{\text { Rendah }}$

Jumlah keseluruhan Kelembapan Udara rendah

$=2 / 11=0.18$

$=$ Jumlah Kelembapan Udara Tinggi

Jumlah keseluruhan Kelembapan Udara tinggi

$$
=1 / 11=0.09
$$

R3 = Jumlah Kelembapan Udara

$\underline{\text { Rendah }}$

Jumlah keseluruhan Kelembapan

Udara rendah

$=2 / 11=0.18$

= Jumlah Kelembapan Udara Tinggi

Jumlah keseluruhan Kelembapan Udara tinggi

$$
=1 / 11=0.09
$$

R7 = $\underline{\text { Jumlah Kelembapan Udara }}$

$\underline{\text { Rendah }}$

Jumlah keseluruhan Kelembapan

Udara rendah

$$
\begin{aligned}
& =2 / 11=0.18 \\
& =\frac{\text { Jumlah Kelembapan Udara Tinggi }}{\text { Jumlah keseluruhan Kelembapan }} \\
& \quad \text { Udara tinggi } \\
& =1 / 11=0.09
\end{aligned}
$$

$\mathrm{R} 4=$ Jumlah Kelembapan Udara

$\underline{\text { Rendah }}$

Jumlah keseluruhan Kelembapan

Udara rendah

$$
\begin{aligned}
&= 1 / 11=0.09 \\
&= \frac{\text { Jumlah Kelembapan Udara Tinggi }}{\text { Jumlah keseluruhan Kelembapan }} \\
& \text { Udara tinggi }
\end{aligned}
$$$$
=2 / 11=0.18
$$

R5 = Jumlah Kelembapan Udara

Rendah

Jumlah keseluruhan Kelembapan

Udara rendah

$$
\begin{aligned}
&= 1 / 11=0.09 \\
&= \frac{\text { Jumlah Kelembapan Udara Tinggi }}{\text { Jumlah keseluruhan Kelembapan }} \\
& \quad \text { Udara tinggi } \\
&=2 / 11=0.18 \\
& \text { R6 } \quad=\quad \text { Jumlah Kelembapan Udara }
\end{aligned}
$$

Rendah

Jumlah keseluruhan Kelembapan

Udara rendah

$$
\begin{aligned}
= & 2 / 11=0.18 \\
= & \frac{\text { Jumlah Kelembapan Udara Tinggi }}{\text { Jumlah keseluruhan Kelembapan }} \\
& \quad \text { Udara tinggi } \\
= & 1 / 11=0.09
\end{aligned}
$$


d) Probabilitas harga pasaran pada setiap kategori jenis rumput

Tabel 8. Probabilitas Harga Pasaran

\begin{tabular}{|c|c|c|c|c|c|c|c|c|c|c|c|c|c|c|}
\hline \multirow{2}{*}{ Himpunan } & \multicolumn{7}{|c|}{ Jumlah Kategori Harga Pasaran } & \multicolumn{7}{|c|}{ Probabilitas Kategori Harga Pasaran } \\
\hline & $\mathbf{R 1}$ & $\mathbf{R 2}$ & $\mathbf{R 3}$ & R4 & $\mathbf{R 5}$ & R6 & R7 & $\mathbf{R 1}$ & $\mathbf{R 2}$ & $\mathbf{R 3}$ & $\mathbf{R 4}$ & $\mathbf{R 5}$ & R6 & R7 \\
\hline Rendah & 3 & 1 & 1 & 1 & 1 & 2 & 2 & 0.27 & 0.09 & 0.09 & 0.09 & 0.09 & 0.18 & 0.18 \\
\hline Tinggi & 1 & 2 & 2 & 2 & 2 & 1 & 1 & 0.09 & 0.18 & 0.18 & 0.18 & 0.18 & 0.09 & 0.09 \\
\hline
\end{tabular}

Penjelasan :

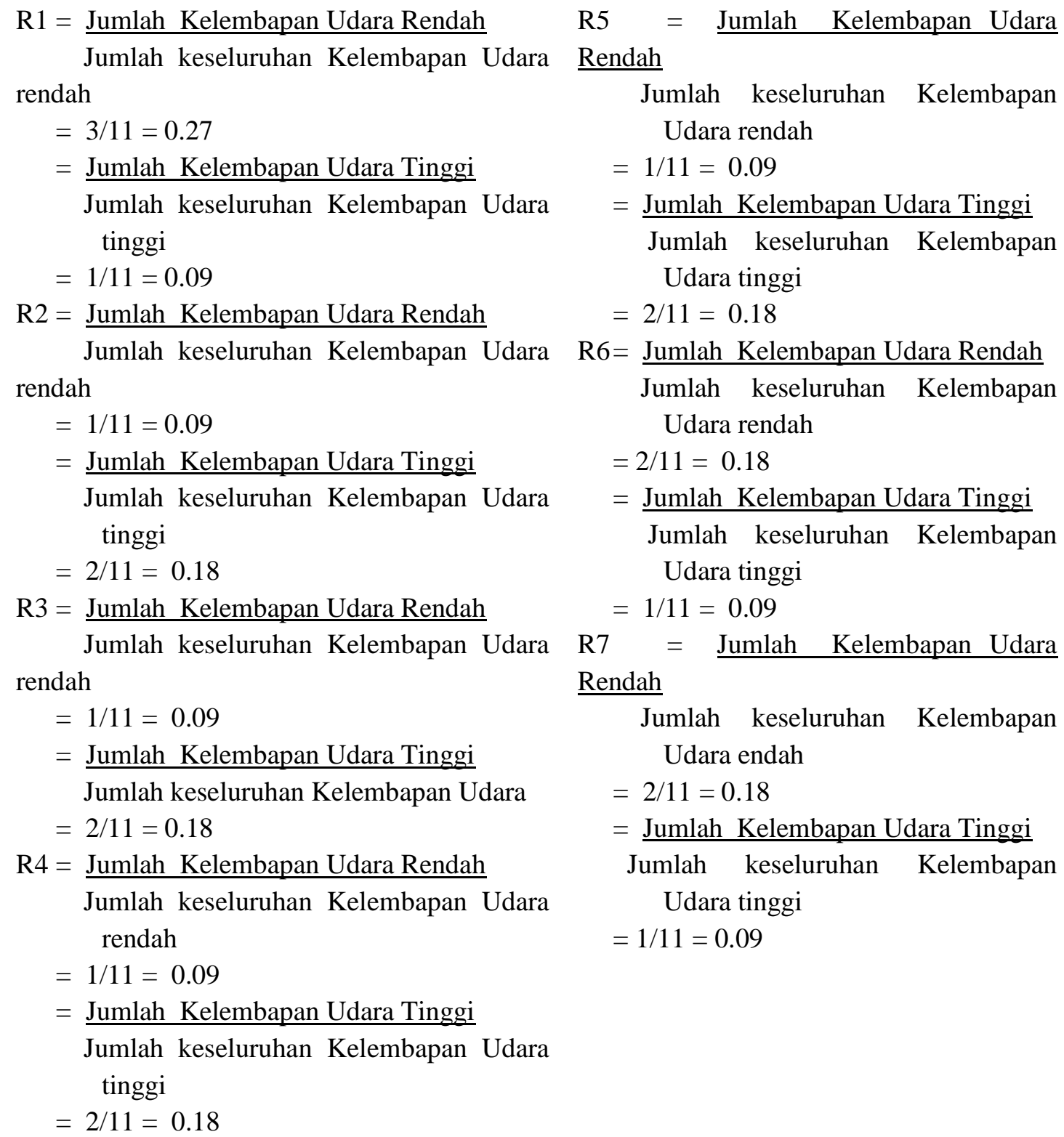


e) Probabilitas untuk setiap kategori pada jenis rumput

Tabel 9. Probabilitas Jenis Rumput

\begin{tabular}{|l|c|c|c|c|c|c|c|}
\hline \multirow{2}{*}{ Himpunan } & \multicolumn{6}{|c|}{ Probabilitas Kriteria Jenis Rumput } \\
\cline { 2 - 8 } & R1 & R2 & R3 & R4 & R5 & R6 & R7 \\
\hline Jumlah & $4 / 22$ & $3 / 22$ & $3 / 22$ & $3 / 22$ & $3 / 22$ & $3 / 22$ & $3 / 22$ \\
\hline
\end{tabular}

Penjelasan :

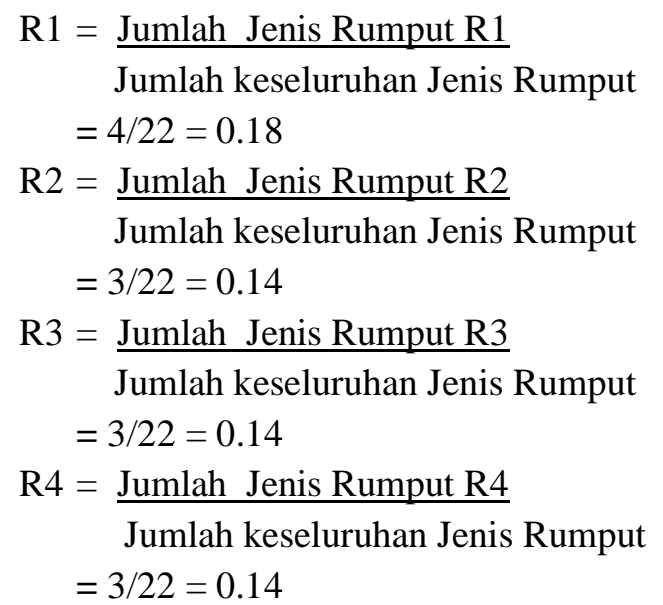
R5 = Jumlah Jenis Rumput R5 Jumlah keseluruhan Jenis Rumput $=3 / 22=0.14$

R6 = Jumlah Jenis Rumput R6 Jumlah keseluruhan Jenis Rumput $=3 / 22=0.14$

R7 = Jumlah Jenis Rumput R7 Jumlah keseluruhan Jenis Rumput $=3 / 22=0.14$

Dalam pengguna menginputkan data kriteria jenis rumput dengan kriteria sebagai berikut :
a. Suhu Udara
: Dingin
b. Curah Hujan
: Tinggi
c. Kelembahan Udara
: Rendah
d. Harga Pasaran
: Rendah

4. Mencari Likelihood

Perhitungan Likelihood

Likelihood R1

$=0.09 * 0.09 * 0.09 * 0.09 * 0.18=0.0000716$

Likelihood R2

$=0.09 * 0.09 * 0.18 * 0.09 * 0.14=0.0000179$

Likelihood R3

$=0.09 * 0.09 * 0.18 * 0.09 * 0.14=0.0000179$

Likelihood R4

$=0.18 * 0.18 * 0.09 * 0.09 * 0.14=0.0000358$

Likelihood R5

$=0.18 * 0.09 * 0.09 * 0.09 * 0.14=0.0000179$

Likelihood R6

$=0.18 * 0.18 * 0.09 * 0.09 * 0.14=0.0001432$

Likelihood R7

$=0.18 * 0.18 * 0.09 * 0.09 * 0.14=0.0001432$

5. Hasil perhitungan

Tabel 10. Hasil Perhitungan

\begin{tabular}{|l|c|}
\hline \multicolumn{1}{|c|}{$\mathrm{R}$} & Hasil \\
\hline $\mathrm{R} 1=0.0000745 /(0.0000186+0.0000186+0.0000373+0.0000186+$ & 0.1904883661 \\
$0.0001490+0.0001490)$ & \\
\hline $\begin{array}{l}\mathrm{R} 2=0.0000179 /(0.0000716+0.0000179+0.0000358+0.0000179+ \\
0.0001432+0.0001432)\end{array}$ & 0.0416666667 \\
\hline $\begin{array}{l}\mathrm{R} 3=0.0000179 /(0.0000716+0.0000179+0.0000358+0.0000179+ \\
0.0001432+0.0001432)\end{array}$ & 0.0416666667 \\
\hline $\begin{array}{l}\mathrm{R} 4=0.0000358 /(0.0000716+0.0000179+0.0000179+0.0000179+ \\
0.0001432+0.0001432)\end{array}$ & 0.0869565217 \\
\hline
\end{tabular}




\begin{tabular}{|l|l|}
\hline$R 5=0.0000179 /(0.0000716+0.0000179+0.0000179+0.0000358+$ & 0.0416666667 \\
$0.0001432+0.0001432)$ & \\
\hline$R 6=0.0001432 /(0.0000716+0.0000179+0.0000179+0.0000358+$ & 0.4705882353 \\
$0.0000179+0.0001432)$ & \\
\hline $\begin{array}{l}\text { R }=0.0001432 /(0.0000716+0.0000179+0.0000179+0.0000358+ \\
0.0000179+0.0001432)\end{array}$ & 0.4705882353 \\
\hline
\end{tabular}

6. Hasil Perangkingan

Tabel 11. Perangkingan

\begin{tabular}{|c|l|c|l|}
\hline Kode & \multicolumn{1}{|c|}{ Nama Rumput } & Nilai Probabilitas & \multicolumn{1}{|c|}{ Keterangan } \\
\hline R7 & Rumput Golf & 0.4705882353 & Kualitas Baik \\
\hline R6 & Rumput Swiss & 0.4705882353 & Kualitas Baik \\
\hline R1 & Gajah Mini & 0.1904761905 & Kualitas Kurang Baik \\
\hline R4 & Rumput Paitan & 0.0869565217 & Kualitas Kurang Baik \\
\hline R5 & Rumput Jepang & 0.0416666667 & Kualitas Kurang Baik \\
\hline R3 & Rumput Paeking & 0.0416666667 & Kualitas Kurang Baik \\
\hline R2 & Gajah Mini Variegata & 0.0416666667 & Kualitas Kurang Baik \\
\hline
\end{tabular}

Berdasarkan perhitungan Naive Bayes (Tabel 10 dan Tabel 11) maka jenis rumput dengan kualitas baik adalah jenis Rumput Golf dan Swiss karena memiliki nilai probabilitas akhir yang sama tinggi yaitu dengan nilai 0.4705882353 .

Sistem yang dibuat memiliki beberapa prosedur kerja, setiap tampilan form memiliki prosedur kerja dan prosedur kerja disesuaikan dengan kebutuhan yang ada pada setiap tampilan form. Form data rumput digunakan untuk menginput data rumput, Gambar 4. Form data kriteria digunakan untuk menginput data kriteria. Form data training digunakan untuk menginput data training, Gambar 4.
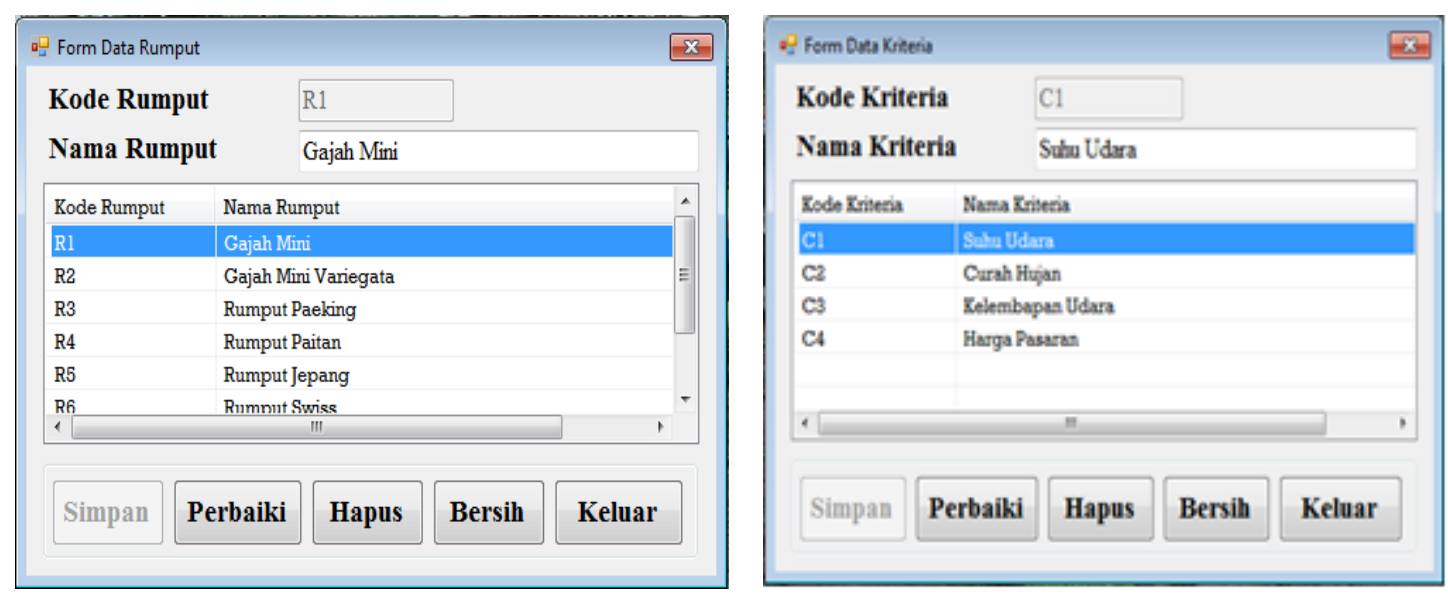

Gambar 4. Form Data Rumput dan Form Kode Kriteria

Form Data Analisa digunakan untuk melakukan proses analisa dengan data rumput dengan menggunakan metode Naive Bayes, Gambar 5. Dalam form data analisa, Gambar 6, terdapat lima tombol diantaranya adalah tombol hitung probabilitas jenis rumput digunakan untuk melakukan perhitungan nilai probabilitas jenis rumput, tombol analisa jenis rumput digunakan 
untuk melakukan proses analisa jenis rumput, tombol simpan data analisa digunakan untuk menyimpan data hasil dari proses analisa, tombol keluar digunakan untuk untuk menutup form.

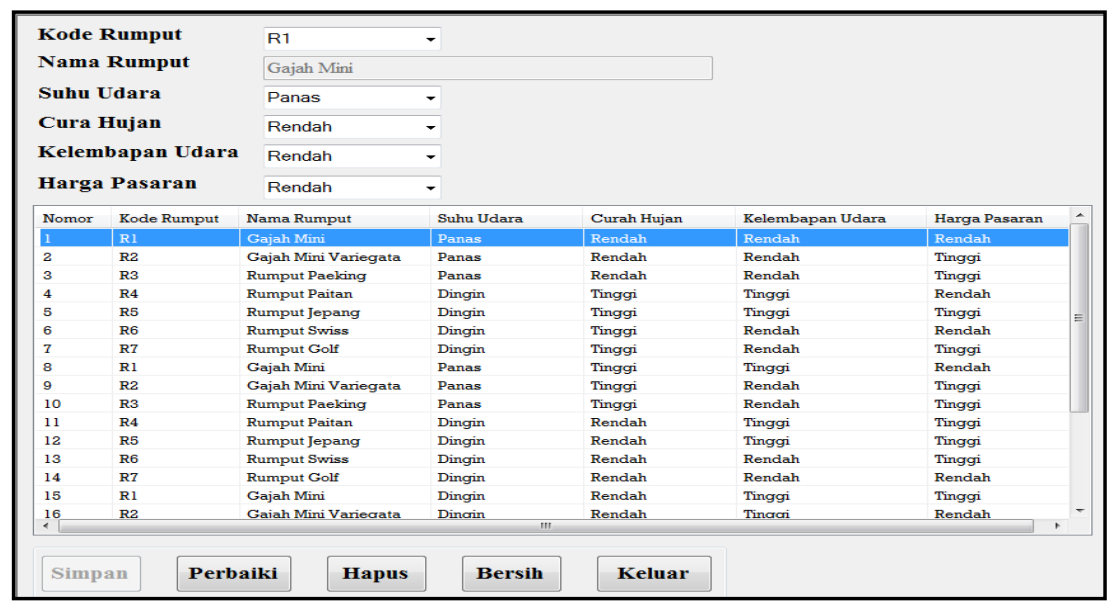

Gambar 5. Form Data Training

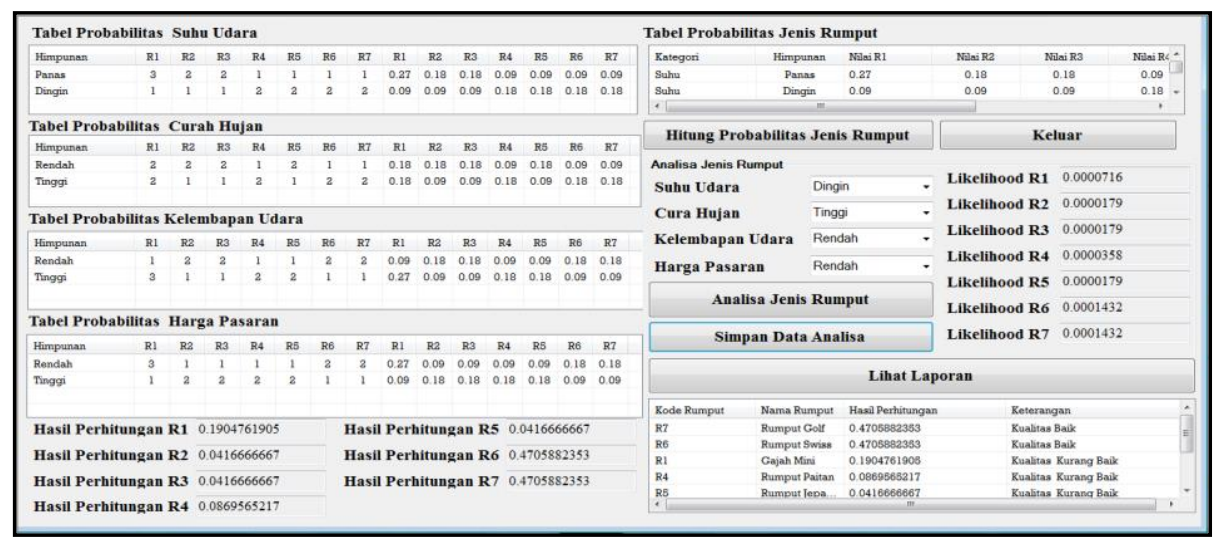

Gambar 6. Form Analisa Data

Setelah proses perhitungan selesai maka sistem akan menampilkan hasil laporan. Berikut adalah tampilan laporan hasil keputusan, Gambar 7.

\begin{tabular}{|c|c|c|c|c|}
\hline \multicolumn{5}{|c|}{$\begin{array}{c}\text { CV. RUMPUT KITA LANDSCAPE } \\
\text { Jln.Bunga Rinte Komp Graha Anggrek Bloc C-26 Simpang Selayang,Medan Tuntungan } 20135\end{array}$} \\
\hline \multicolumn{5}{|c|}{ Laporan Hasil Keputusan Pemilihan Rumput Taman } \\
\hline Nomor & Kode Rumput & Nama Rumput & Hasil & Hasil \\
\hline 1 & $\mathrm{R} 7$ & Rumput Golf & 0.4705882 & Kualitas Baik \\
\hline 2 & $\mathrm{R} 6$ & Rumput Swiss & 0.4705882 & Kualitas Baik \\
\hline 3 & R1 & GajahMini & 0.1904762 & Kualitas Kurang Baik \\
\hline 4 & R4 & Rumput Patan & 0.0869565 & Kualitas Kurang Baik \\
\hline 5 & R5 & Rumput Jepang & 0.0416667 & Kualitas Kurang Baik \\
\hline 6 & R3 & Rumput Paeking & 0.0416667 & Kualitas Kurang Baik \\
\hline 7 & $\mathrm{R} 2$ & GajahMini Variegata & 0.0416667 & Kualitas Kurang Baik \\
\hline \multicolumn{5}{|c|}{ Medan, 22-September-2018 } \\
\hline & & & & inan) \\
\hline
\end{tabular}

Gambar 7. Tampilan Laporan Hasil Keputusan Metode Naïve Bayes 


\section{Kesimpulan}

Berdasarkan hasil dari pengujian sistem pemilihan jenis rumput, dapat diambil kesimpulan :

1. Sistem ini dapat mempertimbangkan konsistensi yang logis dalam penilaian yang digunakan sehingga menghasilkan alternatif yang tidak banyak dibandingkan dengan sistem lama yang tidak memiliki konsistensi yang logis dalam melakukan penilaian dan mampu memberikan keputusan tentang pemilihan kualitas jenis rumput taman secara cepat.

2. Hasil perangkingan dari R1, R2, R3, R4, R5, R6, R7 menunjukkan R6: Rumput Golf= 0.4705882353 ; R7: Rumput Swiss= 0.4705882353 merupakan rumput yang memiliki Kualitas Baik.

3. Metode Naive Bayes sistem yang dibangun menampilkan hasil proses penentuan kualitas jenis rumput taman dan setelah dilakukan penelitian terhadap 7 jenis rumput taman, rumput Swiss dan rumput golf memiliki nilai yang paling tinggi diantara jenis rumput yang lain bukan berarti jenis rumput yang lain tidak memiliki kualitas terbaik sesuai dengan keriteria yang telah diberikan dari pihak CV. Rumput Kita Landscape.

4. Sistem ini harus selalu diadakan perubahan secara berkala untuk menyesuaikan dengan keadaan lingkungan yang terus berubah agar sistem tersebut selalu up to date. Untuk melakukan perbaikan keputusan, sistem ini harus di mulai lagi dari tahap awal.

\section{Daftar Pustaka}

[1] Andri Suryadi, Dian Nurdiana, "Sistem Pendukung Keputusan Seleksi Ujian Masuk Perguruan Tinggi Menggunakan NaÏve Bayes Classifier", Kinetik, November 2016, Vol.1, No.3, Hal. 173-182.

[2] Maskiswo Addi Puspito, Nurul Hidayat, Suprapto, "Sistem Pendukung Keputusan Diagnosa Penyakit Tanaman Jeruk Menggunakan Metode Naive Bayes Classifier", Jurnal Pengembangan Teknologi Informasi dan Ilmu Komputer, Juli 2018, Vol. 2, No. 7, hlm. 2578-2583.

[3] Astrid Novita Putri, "Penerapan Naive Bayesian Untuk Perankingan Kegiatan Di Fakultas Tik Universitas Semarang”, Jurnal SIMETRIS, November 2017 Vol 8 No 2 hal 603-609.

[4] Ketut Artaye, "IMPLEMENTATION OF NAÏVE BAYES CLASSIFICATION METHOD TO PREDICT GRADUATION TIME OF IBI DARMAJAYA SCHOLAR", International Conferences on Information Technology and Business (ICITB)", 2015, p 284-290.

[5] Alfa Saleh, "ImplementasiMetode Klasifikasi Naïve BayesDalam Memprediksi Besarnya PenggunaanListrikRumah Tangga", Citec Journal, Vol. 2, No. 3, Mei 2015 -Juli, hal 207217.

[6] Budi Harijanto, Yuri Ariyanto, Luthfia Miftahurroifa, "Penerapan Algoritma Naïve Bayes Untuk Klasifikasi Retensi Arsip", Jurnal Informatika Polinema, Februari 2018, Volume 4, Edisi 2, hal 155-160.

[7] Fitri Handayani, Feddy Setio Pribadi, "Implementasi Algoritma Naive Bayes Classifier dalam Pengklasifikasian Teks Otomatis Pengaduan dan Pelaporan Masyarakat melalui Layanan Call Center 110", Jurnal Teknik Elektro Vol. 7 No. 1 hal 19-25.

[8] Alfa Saleh, "Implementasi Metode Klasifikasi Naïve Bayes Dalam Memprediksi Besarnya Penggunaan Listrik Rumah Tangga", Citec Journal,Tahun 2015, Vol. 2, No. 3, hal 207-217.

[9] Ali Mahmudi, Moh. Miftakhur Rokhman, Achmat Eko Prasetio, Rancang Bangun Sistem Pakar Untuk Mendiagnosis Tanaman Cabai Menggunakan Metode Bayes, Jurnal Rekayasa Dan Manajemen Sistem Informasi, Vol.2, No 2, Agustus 2016, hal 85-90.

[10] Nur Aini Hutagalung, Implementasi Metode Bayes Pada Sistem Pakar Mendiagnosa Penyakit Polio, JSK (Jurnal Sistem Informasi dan Komputerisasi Akuntansi) Vol 01 No 02, Desember 2017, hal 26-30. 